\title{
SOUTH AFRICAN MARITIME FOREIGN POLICY: RETHINKING THE ROLE OF THE SOUTH AFRICAN NAVY
}

\author{
Mark Blaine and Michelle Nel \\ Stellenbosch University
}

\begin{abstract}
The military is one of the instruments that states use in the implementation of foreign policy within the security domain. As an arm of service, the South African Navy is the instrument of implementation of foreign policy in the maritime domain, playing a role in maritime safety and security as well as environmental protection. ${ }^{1}$

Although the concept of a maritime foreign policy is not defined in the literature, Van Nieuwkerk and Manganyi ${ }^{2}$ propose a working definition in this publication and it is against the background of this definition that the article reports on the traditional roles and classification of navies against the practical reality of an evolving maritime security context. The discussion then turns towards the maritime threats specific to the Southern African Development Community (SADC) while considering South Africa's importance within the region and consequent maritime security responsibility. Considering the SADC Maritime Security Strategy and South Africa's response to maritime insecurity, the study on which this article reports, questioned whether the South African Navy is in fact equipped to deliver on South Africa's maritime foreign policy in its current de facto role of maritime diplomacy.
\end{abstract}

\section{MARITIME SECURITY: ROLES AND CLASSIFICATION OF NAVIES}

The numerous frameworks within which navies function and the divergent roles they play within a foreign policy framework depend largely on the maritime security context within which they function. This section discusses a matrix for maritime security, considering the various naval functions and their consequent classification.

\section{A matrix for maritime security}

Bueger $^{3}$ examined the definition of maritime security and provides a maritime security matrix, which specifies different dimensions for the maritime security concept. In this approach, maritime security is placed in the centre of the matrix with national security, the marine environment, economic development and human security as the outer functions in order to maintain good order at sea. The elements of sea power, marine safety, blue economy and human resilience underpin these functions and direct the tasks or functions of maritime forces. 
Since maritime security defies definition, the matrix in Figure 1 below should be seen as an analytical tool used to understand the functions and interrelatedness of the different concepts and actors in this environment. One could therefore analyse the roles and functions of navies and coastguards in terms of the matrix by determining its focus on and actions against maritime security threats, such as accidents, pollution, smuggling, terrorist acts, arms proliferation, interstate disputes, human trafficking, piracy and illegal, unreported, and unregulated (IUU) fishing. The matrix focuses on the holistic nature of maritime security.

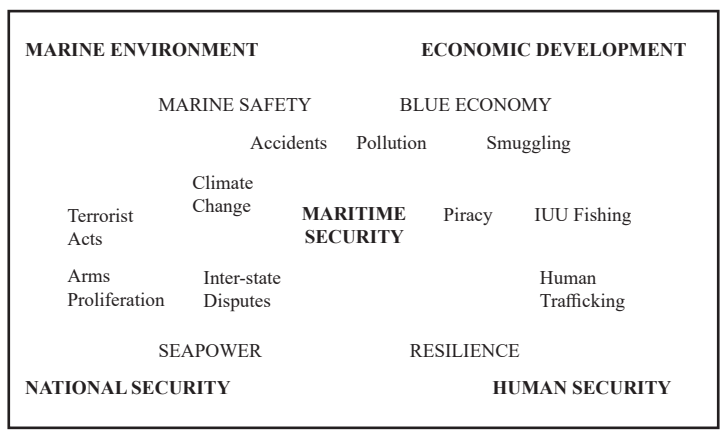

\section{Figure 1: Maritime security matrix ${ }^{4}$}

\section{Naval functions}

As instruments of foreign policy within the Bueger matrix, Booth ${ }^{5}$ (augmented by James Holmes ${ }^{6}$ and Ben Lombardi ${ }^{7}$ ) describes the functions of the navy as a trinity where the use of the sea is seen as the binding factor. The three sides of the trinity elucidate the three functions or roles of navies as military, diplomatic and policing, thereby providing navies with their purpose. Figure 2 graphically depicts the trinity of functions, which are analysed below.

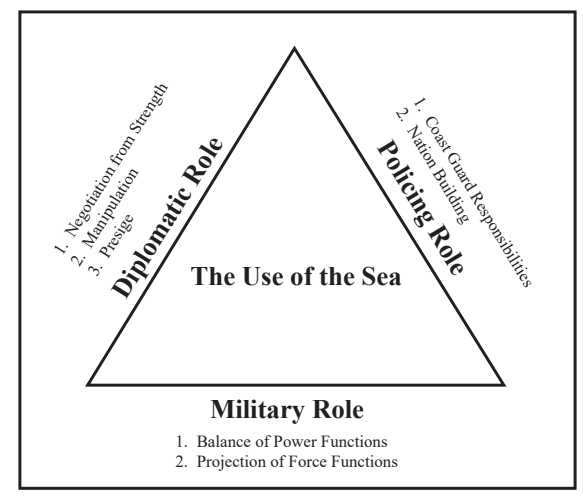

Figure 2: Booth's roles of navies ${ }^{8}$ 
The military role at the base of the triangle is symbolic of the military character of its primary role, providing navies with the ability to threaten or use force thereby giving substance to the other (secondary) roles. The diplomatic role supplements foreign policy short of the actual employment of force, strengthening a nation's position in particular situations or in general international dealings. The policing role relates to the enforcing of sovereignty over the state's own maritime frontiers and is not normally concerned with the armed forces of another state.

Booth emphasises that the different sides of the triangle do not denote equal importance. Different states will confer more importance to each function depending on their own maritime challenges and interests.

\section{Military role}

The military role, as the primary role of most navies, comprises both peace and war operations. Manganyi ${ }^{9}$ divides this military role into two categories. He refers to combat operations at sea (which includes functions, such as intelligence gathering, surveillance and interdiction) and combat operations from the sea where the navy provides amphibious operations and gunfire support. Navies capable of fulfilling this role would also be able to fulfil its policing role.

\section{Policing role}

In its broadest sense, the policing role refers to coastguard responsibilities and nation building. This function or role mainly takes place within territorial waters and broadly relates to the maintenance of public order. It is generally accepted as military aid to civil authority.

Coastguard responsibilities are the most important aspects of policing and comprise the defence of sovereignty, the protection of resources in the adjacent areas as well as the maintenance of good order at sea. These responsibilities do not fall within the exclusive purview of navies and states may task any separate maritime authority, the navy or a combination of these for fulfilment of these responsibilities.

Nation building relates to the use of naval forces in internal stability during natural or political turmoil. Although not prevalent, navies could make useful contributions during natural disasters or civil turmoil, and play a limited role in modernisation in some developing countries.

Although Booth contends that the policing role will never be an important mission to blue water navies, more than one third of the world's navies, coastguards and nation-building responsibilities are primarily focused on this function. For most other nations, such as South Africa, who do not foresee an external maritime threat or who lack the capacity to combat such threats, the secondary role of policing becomes one of their navy's major roles. Such nations thus depend on international stability for the defence of their maritime zones. 


\section{Diplomatic role}

Historically, this role has been an important one for major navies and has evolved into a variety of tasks. These tasks range from those with implicit or explicit coercion (negotiation from a position of strength) to those promising reward (naval aid) and those improving relationships (influence and prestige). The main functions of the diplomatic role are negotiation from a position of strength, manipulation and prestige. Considering its participation in bilateral and multilateral maritime exercises, this has become the major role of the South African (SA) Navy, overshadowing the military and, arguably more relevant, policing roles.

\section{Other views on naval functions}

Feldt ${ }^{10}$ analysed the maritime domain from a civil-military perspective and defines the roles of navies in relation to maritime defence and deterrence, crisis response, naval diplomacy and maritime capacity building. He contends that specific naval roles would cover the entire spectrum from low intensity to war-fighting tasks.

Leadmark $^{11}$ extensively elaborates on the roles of navies by drawing from both the Booth model and the Grove ${ }^{12}$ classification of navies, expanding the Booth diagram to reflect the following:

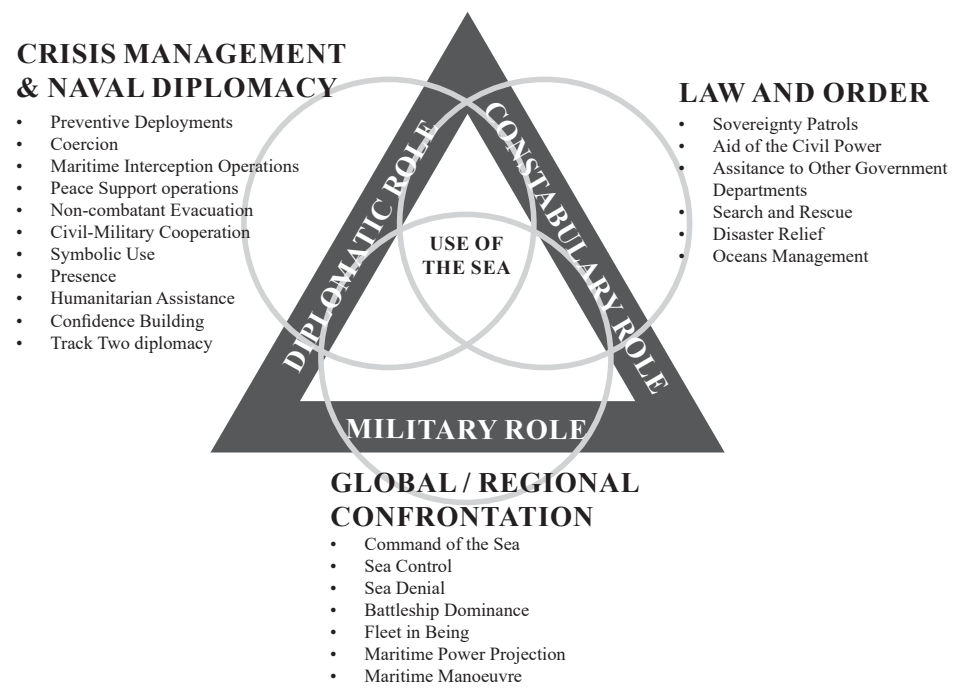

Figure 3: Leadmark maritime security matrix ${ }^{13}$

These varied roles and functions of navies provides a framework for classifying navies. The next section discusses the current maritime security situation in the Southern African Development Community (SADC) region, focusing on a selection of threats to good order at sea and the responses by specifically the SA Navy as arguably the only credible naval force in the region ${ }^{14}$. 


\section{MARITIME SECURITY IN THE SADC REGION}

This section will elucidate the current maritime security situation in the SADC region by highlighting the threats experienced, the continental and regional strategic initiatives to counter such threats as well as the unilateral and regional actions taken by the SA Navy to mitigate the threats.

\section{Maritime threats to SADC}

Due to its geographical location and perceived capacity, South Africa is regarded as an important role player in SADC maritime security. Maritime threats of SADC can thus conceivably be seen as maritime threats of South Africa, with South African foreign policy consequently influencing what is happening in the SADC.

Good order at sea requires the creation of collaborative maritime security architectures to allow the conduct of free trade in a safe and secure environment, allowing the blue economy to flourish. This architecture strengthens maritime institutions, enabling such institutions to regulate the fishing industry better, enhance actions against illegal acts such as piracy, smuggling, illicit trade and cross-border crime, combatting environmental threats such as plastics pollution, as well as ensuring safe navigation of shipping. ${ }^{15}$

\section{Piracy and armed robbery}

Whilst a lack of maritime domain awareness increases the likelihood of piracy incidents, the notoriously rough seas and inhospitable coasts in the SADC area of operations inhibit such incidents. ${ }^{16}$ Incidents of piracy or attempted piracy and armed robbery at sea are however not new to SADC waters. This is clearly illustrated by the 2010 attacks on two fishing vessels close to the coast of Mozambique as well as reported failed incidents off the coast of Beira. ${ }^{17}$ On the west coast of Africa, the oil tanker MT Kerala was hijacked off Angola in January 2014, and returned one week later after diesel worth around US\$8 million had been stolen, raising concerns of piracy and armed robbery at sea possibly spreading southward from the Gulf of Guinea. ${ }^{18}$

\section{Maritime terrorism}

The relative prosperity and weak institutional systems of the SADC region create an attractive environment and target for transnational terrorist groups. The threat of global terrorism in Southern Africa is a further matter of concern due to the known connections between this region and terrorist activity in Africa and beyond. Long and porous borders exacerbated by weak governance, the growing radicalisation of the Southern African migrant populations as well as the local Muslim communities can be seen as contributing factors of a climate conducive to international terrorism and spill-over effects that, although more landward focused, do not exclude the sea. ${ }^{19}$ 


\section{Trafficking and smuggling}

The SADC region is prone to human trafficking due to the vulnerabilities created by war, poverty, absence of facilities for health and education, gender and economic inequality as well as unemployment. ${ }^{20}$

Mozambique and Angola have been identified as two major trafficking hubs in the SADC, with human trafficking in Madagascar increasing significantly since 2009, mainly due to the political crisis in the island nation. ${ }^{21}$ Tanzania has further been identified as one of the five leading conduits for illicit drug trafficking in the region; the others being Mozambique, South Africa, Namibia and Angola. ${ }^{22}$

The absence of adequate patrol capabilities in harbours and coastal waters of the SADC will exacerbate the occurrence of human and other trafficking or smuggling. Traditionally considered a landward threat, countries have only recently turned their attention offshore. In this context, Mozambique has signed an agreement in September 2013 to purchase six patrol and interceptor vessels for its navy designed for anti-piracy and anti-terrorism activities and countering illicit trafficking. ${ }^{23}$

\section{Illegal fishing and poaching}

Fishing provides a major source of protein to the continent, and any threat to the sector will be a major threat to the food security on the continent as a whole. ${ }^{24}$ Statistics indicate that South Africa, Angola, Namibia and Tanzania are the major actors in this sector. While the Tanzanian growth can be attributed to the scale of the tuna industry in the Indian Ocean, the sectors in South Africa, Namibia and Angola are all positively influenced by the rich supply of fish in the cold Benguela Current on the west coast. ${ }^{25}$

The IUU fishing in the region has been influenced by the decimation of the Patagonian tooth fish stocks in the Southern Oceans since 1998, the use of gill nets in the coastal waters of mainly Mozambique for sharks, fishing far beyond the mandate of allocated quotas, and the use of illegal gear, such as fine mesh nets and even dynamite. The effect of IUU fishing in the region can be felt in the economic, ecosystem and social spheres. ${ }^{26}$

Due to the nature of IUU, it is extremely difficult to obtain accurate information on any such activities. The annual loss associated with IUU in the SADC is estimated at approximately US $\$ 50$ million for Angola, US $\$ 40$ million for Mozambique and US\$37 for Madagascar. While statistics for South Africa and Namibia are not readily available, it is agreed that the loss would be worse than in the remainder of the SADC member states. ${ }^{27}$

\section{Inefficient and insecure commercial ports}

The maritime sector plays a major role in the economic well-being of all littoral countries and significantly influences the economies of landlocked countries as well. Problems experienced at any of the ports of the region would have a negative effect on the economies across the region. Some of the identified threats to port security are: theft and hijacking of ships or service vessels, use of ships to transport illegal goods 
or persons, blockage of the port, and the use of ships tied up alongside the harbour as weapons. ${ }^{28}$ More than $65 \%$ of attacks against ships take place while they are at anchor in or alongside any given port, encompassing acts of corruption (including extortion and collusion with criminal elements) and sea robbery. These very acts need to be curtailed in order to ensure adequate port security. ${ }^{29}$

\section{Continental and regional strategic initiatives}

The Brenthurst foundation postulates that maritime security is a key component of collective security which directly affects economic prosperity ${ }^{30}$. Kornegay similarly states that the range of maritime security challenges and its international implications should focus the attention on a continental and regional approach to address the interregional and continental maritime challenges around the coast of Africa ${ }^{31}$. No one country can thus tackle maritime security on its own. What is needed in this regard is continental and specifically regional direction and cooperation.

\section{Africa's Integrated Maritime Strategy 2050 (AIMS 2050)}

AIMS 2050, adopted by the African Union (AU) in 2012, recognises the vast potential for wealth creation in the maritime domain for the continent, that all member states have common maritime challenges, opportunities and responsibilities, requiring the requisite political will for implementing a common strategy. An AIMS 2050 Task Force was created in 2011 with the task of establishing a Department of Maritime Affairs (to develop and coordinate all policy implementation). Each regional economic community (REC) within the AU is also required to have a focal point and to establish a steering committee as well as develop an evaluation and monitoring tool. ${ }^{32}$

AIMS 2050 further charges the RECs to "develop, coordinate and harmonise policies and strategies and improve African maritime security and safety standards as well as the African maritime economy. ${ }^{33}$

\section{The SADC Maritime Security Strategy}

Due to its geographical position on the Cape sea route linking the Atlantic and Indian oceans, the South African economy relative to that of other SADC states, its maritime infrastructures and its capacity to deal with maritime security challenges, make the country the ideal candidate for taking the initiative in responding to challenges to good order at sea within the SADC region. South Africa therefore took the lead in developing an SADC maritime security strategy, endorsed by the SADC Organ on Politics, Defence and Security ${ }^{34}$, on 14 June 2011 . The SADC maritime security strategy to counter maritime insecurity in SADC's Indian Ocean region focuses the strategy on the elimination of piracy in the SADC's Eastern Indian Ocean. The strategy has not yet been released publicly but cites three priorities: the eradication of Somali piracy in Southern Africa; securing the west coast of Southern Africa; and securing Southern Africa's vast rivers and lakes. ${ }^{35}$ 
The strategy could be seen as 'South Africa-driven' and reflects mostly South African interests while highlighting the country's dichotomy in the region - balancing South Africa's geo-strategic motives as self-appointed rescuer in the region while not adequately addressing domestic challenges in respect of other maritime security issues, such as trafficking, IUU fishing, environmental protection and disaster response. ${ }^{36} \mathrm{Al}-$ though the SADC maritime security strategy is titled "maritime security strategy", it does not adequately address the whole ambit of maritime insecurity and may thus be insufficient to deal with the holistic concept of good order at sea ${ }^{37}$ The execution of the strategy resulted in the formation of a SADC maritime task force (Operation Copper), which focused almost exclusively on anti-piracy operations. ${ }^{38}$

\section{South African responses to maritime insecurity}

The maritime security dimension of South Africa's foreign policy relates to good order at sea in order to support the blue economy so as to achieve socio-economic development, and is operationalised through Operation Phakisa.

\section{Maritime policy and strategy}

Although South Africa took the lead in developing the SADC maritime security strategy, the country does not have an integrated national maritime security policy or strategy of its own. Despite numerous attempts to develop such a policy or strategy and general consensus that a coherent national-interest framework is required in order to take a proactive stance in maritime security affairs, neither an integrated maritime security policy or strategy has ever been implemented officially. Instead, various government departments have developed their own policies and strategies. ${ }^{39}$

\section{Maritime border safeguarding}

The South African Defence Review 2014 states, "South Africa's borders and strategic installations will be safeguarded ${ }^{40}$ by the Defence Force in conjunction with other Departments". It further states, "Defence will assume full responsibility for land, air and maritime border safeguarding" and that "[t]his will be pursued with Defence leading all collaborative efforts concerning safeguarding on the border-line ${ }^{41}$ and the immediate rear areas." ${ }^{42}$ This is a fundamental departure from the Defence Review of 1998, in that in this latter review, the responsibility for border safeguarding was allocated to the South African Police Service.

Maritime border safeguarding is currently conducted by the South African National Defence Force (SANDF) under the auspices of Operation Corona, which plans and conducts land, sea and air border-line safeguarding as a component of the defence of the territorial integrity and sovereignty of the Republic of South Africa, the domestic layer of defence in the layered defence concept of the SANDF. ${ }^{43}$ The maritime border safeguarding concept for the short and medium term focuses on deterrence and the enforcement of state authority at sea from the territorial sea out to the exclusive economic zone and later to the extended continental shelf. This will be done through the ad hoc deployment of naval and air assets supported by Maritime Domain Awareness 
(MDA). The concept also sanctions the ad hoc deployment of maritime surface and air assets into adjacent waters of Namibia and Mozambique during approved multinational operations to extend deterrence beyond South African waters and to enhance MDA. ${ }^{44}$

Although the border safeguarding concept prescribes collaboration with other government departments and agencies, of which 18 departments and agencies bear responsibility for some form of border control or another, many academics and security practitioners believe that mere co-ordination between departments and agencies is not sufficient, and have been calling for a more integrated approach to border safeguarding. ${ }^{45}$ Consequently, a border management authority (BMA) was created to house all border functions under one entity, headed by the Department of Home Affairs. Although this may be seen as a step in the right direction, the proposed BMA has not been welcomed by other government departments responsible for certain border management functions. Arguments range from a too broad mandate to what is regarded as an interference with the constitutionally mandated function of the South African Police Service (SAPS). The Bill to establish the BMA has been languishing in the parliamentary process for nine years, with departmental infighting hampering its successful implementation. ${ }^{46}$ The establishment of the BMA might have a major influence on the roles and responsibilities of the SAPS, the SANDF and the SA Navy in particular. As it is envisaged that the BMA will function as a separate armed service, the extent of the influence will depend on whether the BMA will remain responsible for ports of entry only, as speculated, or whether it will assume responsibility for patrolling all borders, including the maritime border up to the extent of the exclusive economic zone (EEZ). ${ }^{47}$

\section{Maritime domain awareness (MDA)}

MDA is a crucial component in the concept for maritime border safeguarding and maritime defence. To this end, the SA Navy is in the process of establishing Maritime Domain Awareness Centres (MDACs) in Durban and Cape Town respectively. These MDACs will eventually link with Maritime Security Centres (MSCs) that are being established in Tanzania and Mozambique. MSCs are also being established in Angola and Namibia, but are not yet linked, with Botswana, Lesotho, Malawi, Zambia and Zimbabwe having established operational frameworks to facilitate the necessary links with MDACs and MSCs. ${ }^{48}$

Various other government departments and agencies in South Africa possess databases, information centres and coordination facilities that are relevant to MDA. Although these departments and agencies are linked and share information to some degree, there is no formal process to fuse the information and data, or to do integrated analyses regarding possible threats and risks.

\section{Memorandum on tripartite maritime security}

A memorandum of understanding $(\mathrm{MoU})$ on maritime security co-operation between South Africa, Mozambique and Tanzania was signed in February 2012 in an effort to secure sea borders and tackle the problem of maritime piracy. It was believed that this effort would also reduce trafficking and illegal fishing. It allowed for multifaceted 
maritime security operations, such as information sharing, surveillance, conducting joint military exercises and operations, patrolling, hot pursuit, arrest and search and seizure. $^{49}$ Tanzania withdrew from the MoU early in 2013, while Mozambique continued to provide personnel on board SA Navy ships involved in Operation Copper. ${ }^{50}$

\section{Search and rescue $(S A R)$}

A multilateral agreement between South Africa, Madagascar, the Comoros and Mozambique, signed in 2007, makes provision for co-operation in SAR in areas adjacent to the coast. ${ }^{51}$ The main Maritime Rescue Coordination Centre (MRCC) for Navarea VII is in Silvermine with sub-centres in Walvis Bay, Durban, Dar es Salaam and the Seychelles. The responsibility regarding the international convention for the safety of life at sea (SOLAS) is associated with the Department of Transport (South African Maritime Safety Authority [SAMSA]) in South Africa with the department having a permanent seat at the International Maritime Organisation (IMO) There is however no coordination with the South African National Hydrographic Organisation (SANHO). It would seem that the regional coordination is problematic while international co-operation is very successful. ${ }^{52}$

\section{Promoting safe passage}

As a member of the International Hydrographic Organisation (IHO) since 1951, SANHO has been tasked with the charting of region $\mathrm{H}$ (a large ocean area around Southern Africa stretching all the way to Antarctica), contributing to charting for region M (Antarctica) and coordination of maritime safety information. South Africa drew up a hydrographic co-operation plan for the Standing Maritime Committee of the SADC, which is currently in force, and urged member states to apply for membership of the IHO. ${ }^{53}$ The Southern Africa and Islands Hydrographic Commission (SAIHC) was established in 1996 with SADC members being members or associate members. The aim of the SAIHC is to improve hydrography in the region with the focus on capacity building. In the SADC maritime area, South Africa produces hydrographic information for Namibia and its own shores, while Portugal covers Angola, France covers Madagascar, India covers the Seychelles and the United Kingdom covers Mozambique and Tanzania. Mozambique has a very small hydrographic office, but has no production capability. ${ }^{54}$

\section{Exercises and symposia}

In its maritime diplomacy role, South Africa participates in a number of maritime exercises. Interop East/West is held annually along the coast of Africa. Although initiated by South Africa, all SADC member states are encouraged to send representatives. The exercise focuses on search and rescue, ship safety exercises, seamanship and joint and multilateral co-operation. Exercise Good Tidings, an exercise in riverine operations, was held in Malawi in September 2011 with further similar SADC-sanctioned exercises scheduled in other member states annually. The SA Navy participates biannually in Exercises Ibsamar (India, Brazil and South Africa) and Atlasur (South Africa, Argentina, Brazil and Uruguay). These exercises facilitate interoperability, enhance readiness and develop doctrine, tactics and operating procedures. Plans are at an advanced stage to 
invite navies on the African west coast to Exercise Atlantic Tidings, which would run parallel with the aforementioned exercises. As part of the Standing Maritime Committee of the SADC, the participating countries discuss force support co-operation plans, naval training co-operation plans, hydrographic co-operation plans and naval coordination and guidance of shipping co-operation plans. ${ }^{55}$

The need for a maritime platform to raise and discuss maritime issues common to Africa led to the Seapower for Africa Symposium (SPAS) concept, initiated by chiefs of navies of Ghana, Kenya, Nigeria and South Africa in 2003 at an International Sea Power Symposium in Rhode Island, USA. The first such symposium was held in Cape Town in August 2005 where 23 African nations attended with subsequent symposia held in Nigeria and planned for the rest of Africa. The common themes discussed at these symposia are:

- charting Africa's maritime zones;

- piracy and maritime crime off the coast of Africa;

- patrol and control of Africa's vast maritime hydrocarbon resources;

- controlling Africa's maritime choke points;

- enhancing African maritime regional maritime co-operation: areas of scientific and technology support; and

- maritime, inland waters and riverine disaster management.

The SPAS identified:

- a need for structured continental and regional co-operation to address matters of maritime security and governance;

- the need to maximise potential areas of continental and regional co-operation;

- the requirement to establish continental and regional agreements, arrangements and capabilities;

- the inclusion of all landlocked countries in deliberations; and

- the need to capacitate and support the Maritime Office of the AU.

In order to realise the above themes, the SPAS identified:

- the need for the generation of a comprehensive maritime security policy for Africa;

- the recognition of the importance of collective continental and regional ownership and support of all issues pertaining to maritime governance;

- the requirement for the harmonisation of laws, policies and institutions to facilitate efficient co-operation and collaboration in pursuit of ensuring maritime security continentally and regionally; and

- the need to explore the legal framework as a method of providing mechanisms of co-operation. 
The overriding obligation was placed on all African countries to bring to the attention of their people and their governments the critical importance of the maritime domain to their economic well-being. ${ }^{56}$ In spite of the importance of the SPAS concept, it lacked longevity and has since become dormant. Revival of the concept may prove critical in securing long-term maritime security for Africa and its regions.

The numerous documents and strategies discussed, and the functions and roles contained therein are necessary for the protection of South Africa's maritime interests as reflected in Van Nieuwkerk and Manganyi's definition ${ }^{57}$, thereby informing South African maritime foreign policy. The discussion now turns to the question whether the SA Navy, as an instrument of maritime foreign policy, is in fact equipped to deliver in its current format and function, interrogating the utility of navies and coastguard functions. The complexity of maritime security coupled with a lack of capacity challenges any African state in securing its maritime domain on its own. Consideration is given to the need for regional co-operation in pursuit of its delivery on maritime foreign policy.

\section{RETHINKING THE ROLE OF THE SOUTH AFRICAN NAVY}

As far back as 2009, Vogel ${ }^{58}$ identified the increase in security threats in the African maritime domain, exacerbated by the misalignment of the security structures on the continent. He contends that intergovernmental partnerships as well as the establishment of a coastguard function would be required to address the issue adequately. He proposed five dimensions that differentiate coastguards from navies (summarised in Figure 4). The final column denotes the current situation in Africa, highlighting the fact that most of the maritime forces or organisations relate more closely to coastguards than to navies. In his analysis of the current maritime security situation in Africa, Vogel recommends that assets need to be matched to needs, inter-ministerial collaboration needs to be enhanced, and nations need to engage in effective capacity building in the maritime domain.

\begin{tabular}{|l|l|l|l|}
\hline Missions & \multicolumn{1}{|c|}{ Coastguard } & \multicolumn{1}{|c|}{ Navy } & African maritime forces \\
\hline \multirow{2}{*}{ Assets } & $\begin{array}{l}\text { Maritime safety, law } \\
\text { enforcement, environ- } \\
\text { mental protection, and } \\
\text { border security within } \\
\text { EEZ }\end{array}$ & $\begin{array}{l}\text { War, international sea } \\
\text { lanes, and foreign policy } \\
\text { on high seas or outside of } \\
\text { national boundaries }\end{array}$ & $\begin{array}{l}\text { Primarily maritime } \\
\text { safety, law enforcement, } \\
\text { environmental protection, } \\
\text { and border security } \\
\text { within EEZ, some foreign } \\
\text { policy and peacekeeping } \\
\text { abroad }\end{array}$ \\
& $\begin{array}{l}\text { Tugs, patrol cutters, } \\
\text { aids to navigation, } \\
\text { harbour patrol and } \\
\text { other small boats, fixed } \\
\text { and rotary wing aircraft } \\
\text { for search and rescue, } \\
\text { interdiction }\end{array}$ & $\begin{array}{l}\text { Amphibious landing } \\
\text { ships, surface combatants, } \\
\text { vessels for aerial warfare, } \\
\text { submarines, support } \\
\text { vessels }\end{array}$ & $\begin{array}{l}\text { Hodgepodge of } \\
\text { donations, corvettes, } \\
\text { small patrol boats, some } \\
\text { amphibious landing craft, } \\
\text { and submarines }\end{array}$ \\
\hline
\end{tabular}




\begin{tabular}{|l|l|l|l|}
\hline \multicolumn{1}{|c|}{ Coastguard } & Navy & African maritime forces \\
\hline affiliation & $\begin{array}{l}\text { Various: homeland } \\
\text { security, department of } \\
\text { fisheries and oceans, } \\
\text { ministry of infrastruc- } \\
\text { ture and transport }\end{array}$ & $\begin{array}{l}\text { Ministry or department of } \\
\text { defence }\end{array}$ & $\begin{array}{l}\text { Ministry or department of } \\
\text { defence }\end{array}$ \\
\hline Training & $\begin{array}{l}\text { Operations of assets, } \\
\text { coastguard missions }\end{array}$ & Operation of assets, war & Operations of assets, war \\
\hline Partnerships & $\begin{array}{l}\text { National (judicial, } \\
\text { fisheries, ports, etc.) }\end{array}$ & $\begin{array}{l}\text { Military (army, air force, } \\
\text { etc.) }\end{array}$ & $\begin{array}{l}\text { National (judicial, fisher- } \\
\text { ies, ports, etc.) }\end{array}$ \\
\hline
\end{tabular}

\section{Figure 4: Navies vs coastguards (African realities)}

Paleri posits that coastguards exist to secure the maritime domain through functions not primarily related to war. While navies conduct combat in war situations, coastguards perform in "other than war" situations by enforcement and services in the interest of the country inside the maritime zones. The coastguard can be classified as an armed force with powers of law enforcement but it cannot be classified as a combat force. They are mandated to serve the maritime community with its authority embedded in the mandate. ${ }^{59}$

In South Africa, the Department of Defence indicated in 2017 that it was investigating the possibility of establishing a coastguard over the medium term, but that it would be dependent on funding. It stated that some of the functions of the SA Navy could be transferred to such a coastguard:

- search and rescue (SA Maritime Safety Authority);

- combating of pollution (Department of Environmental Affairs);

- fishery protection (Department of Agriculture, Forestry and Fishery); and

- anti-piracy operations (law enforcement agencies).

Critics of the above study contend that the SA Navy could continue to perform these tasks as part of its secondary function and that the service would lose many of its personnel to such an organisation. ${ }^{60}$ The establishment of such a force would have to be done in conjunction with the proposed BMA Bill discussed above and could have dire consequences for the SA Navy in this regard.

\section{Legal framework}

In the argument regarding whether a country, or a region for that matter, should opt for a navy or a coastguard, and whether the legal framework exists, it would be too simplistic to consider only the navy or coastguard as role players within the maritime domain. Although the United Nations Convention on the Law of the Sea (UNCLOS) remains the bedrock of all subsequent treaties, declarations and legal frameworks in the 
maritime domain, it should be noted that it was negotiated at a time when modern ocean governance looked different. Ocean governance is no longer the exclusive domain of the state. ${ }^{61}$ There are numerous role players, organisations and government departments that play a significant role within the exploitation and protection of the maritime domain. A navy or a coastguard would ultimately carry the main responsibility of ensuring security of this domain, but what would constitute best practices and an ultimate choice of entity would be significantly affected by the relevant role players. At national level, the navy and/or coastguard, transport ministries, police services, the judiciary, policymakers and civil society, to name a few, all have stakes in the maritime domain. This leads to fragmented rules, regulations and operations, executed in specific maritime jurisdictional zones in an environment characterised by the trans-border realities of crime and highly migratory fish stocks.

Although the maritime environment has traditionally not received the attention given to matters on land, ${ }^{62}$ the perceived 'sea blindness' of African countries is purportedly clearing. ${ }^{63}$ The literature is clear on the concerted effort of the African Union (AU) and other regional organisations to create policy documents, treaties and declarations to ensure Africa's blue economy. As a case in point, AIMS 2050 is a tool in addressing Africa's maritime challenges to ensure sustainable development and foster wealth creation from Africa's oceans and inland waterways, in an environmentally sustainable manner. With 38 out of the 54 African states being littoral states and two-thirds of its equivalent land mass in its maritime zones under the sea, the importance of the maritime environment for Africa's sustainable development cannot be emphasised enough. Over $90 \%$ of its trade is conducted by sea. ${ }^{64}$ The size of its maritime resources alone is placing unprecedented strain on the limited maritime security resources individual African countries have at their disposal, a matter clearly exacerbated by the proliferation of maritime crimes and other security challenges.

The vastness of the maritime borders and the scope of the threat to maritime security therefore necessitate co-operation between neighbouring countries and regions if there is any hope in securing Africa's blue economy. The need for regional co-operation has been re-iterated at various forums ${ }^{65}$ Co-operation is a thread that runs through all the conventions and declarations that make up the building blocks of contemporary African maritime security.

As stated above, the ultimate framework for maritime security during times of peace is UNCLOS. ${ }^{66}$ Although it is unclear to what extent the provisions of UNCLOS can be regarded as customary international law, it has been widely accepted as the blueprint for maritime security, and to date has been ratified by 168 parties, 47 of which are African states. ${ }^{67}$ The preamble of UNCLOS sets the tone of co-operation in that it confirms the reason behind the rules that govern the sea was -

[A] desire to settle, in a spirit of mutual understanding and co-operation, all issues relating to the law of the sea and aware of the ... significance of this Convention as an important contribution to the maintenance of peace, justice and progress for all peoples of the world. ${ }^{68}$ 
The spirit of co-operation was taken up in AIMS 2050 with the strategic end state of the strategy being -“"

Increased wealth creation from the $\mathrm{AMD}^{69}$ that positively contributes to socio-economic development, as well as increased national, regional and continental stability, through collaborative, coordinated, coherent and trust-building multi-layered efforts to build block of maritime sector activities in concert with improving elements of maritime governance. $^{70}$

At a regional level, the Djibouti Code of Conduct ${ }^{71}$ was the first regional attempt to address African maritime insecurity, confirming the inability of states to address insecurity on their own and reiterating the need for regional co-operation. ${ }^{72}$ This Code focuses on the repression of piracy within the east coast region of Africa ${ }^{73}$ This was swiftly followed by the Code of Conduct Concerning the Repression of Piracy, Armed Robbery against Ships, and Illicit Maritime Activity in West and Central Africa (the Yaoundé Declaration ${ }^{74}$ ) in order to increase regional co-operation on a number of maritime security issues. The Declaration was concluded between the Economic Community of Central African States (ECCAS), the Economic Community of West African States (ECOWAS) and the Gulf of Guinea Commission (GGC). The Yaoundé Declaration is clear in its recognition of co-operation as the preamble refers to -

[The] crucial role of cooperation at the global, regional, sub-regional, and bi-lateral levels in combatting, in accordance with international law, threats to maritime security ... [underscores] the importance of enhancing international cooperation at all levels to fight transnational organized criminal activities.

One such example is the Maritime Organisation of West and Central African States (MOWCA), which (in conjunction with the IMO) established an MoU in 2008 on the establishment of a sub-regional integrated coastguard network, which proposed joint efforts in dealing with maritime security. to date To date, the MoU has been signed by 16 of the coastal states, and provides a framework for regional maritime co-operation, which in turn relates to peace, good order and prosperity in the Gulf of Guinea (GoG) region. ${ }^{75}$ The coastguard networks enhance maritime domain awareness, improve co-operation and urge increased commitment to treaties, agreements and protocols. It was agreed to divide the region into four coastguard zones ${ }^{76}$ in order to ensure more effective coordination while member states were urged to accelerate the establishment of such coastguard services under the administration of the relevant administrations to support these processes. ${ }^{77}$

The declarations and conventions mentioned above show that the legal framework is in place in order for states to conduct their maritime security, and there is specific emphasis on the fact the regional co-operation is critical for successful maritime security. As important as AIMS 2050 remains as a strategy for African maritime security, it carries no legal weight since it has no binding legal authority to enforce the aims and 
ideals characterising it. The African Charter on Maritime Security and Safety and Development in Africa ${ }^{78}$ (the Lomé Charter) legally enforces these ideals. ${ }^{79}$ The efficacy and the challenges regarding the implementation of the Lomé Charter fall outside this discussion, but the lack of support by a number of littoral states, such as South Africa that have a critical role to play within the maritime security domain, must be noted. ${ }^{80}$

Overall, in an African context, there is a seemingly sufficient framework, both normatively and legally, to support regional co-operation within the maritime domain. States may freely enter into bi-lateral or multilateral agreements in order to enhance their limited capacity. This is also true for regional organisations. AIMS 2050 specifically provides for a number of frameworks on a strategic level to assist states in facilitating co-operation across states and regions. Article 31 of AIMS 2050 provides, inter alia, for a naval component of the African Standby Force (ASF) as well as a continental working group of chiefs of African navies and/or coastguards whose task it would be to look at matters of maritime domain awareness and uphold co-operation between the navies and coastguards of member states. Unfortunately, there has been no discernible progress towards the implementation of these strategic imperatives. Coupled with the lack of support in signing and ratification of the Lomé Charter this raises serious concerns regarding the political will to ensure maritime security versus merely paying lip service at relevant forums.

\section{Situation in SADC}

Placing the SADC as a region under scrutiny, the situation seems dire. In this context, apart from UNCLOS and AIMS 2050, the most relevant documents for creating a legal maritime security framework would arguably be the Lomé Charter, the Djibouti Code of Conduct with its subsequent Jeddah Amendment (the Amended Djibouti Code of Conduct) as well as the SADC Maritime Security Strategy. These documents should be considered against the security situation in the region.

Considering data gathered by the Stable Seas Index, ${ }^{81}$ one can form a clearer picture regarding the overall security situation within the SADC region. Although Stable Seas make use of a number of indicators in determining the overall maritime security situation in sub-Saharan Africa, matters of 'international cooperation' and 'maritime enforcement' are of specific interest to this article. In considering the level of international co-operation, Stable Seas evaluated African countries on their "commitment to multilateral efforts that facilitate maritime security and Governance". ${ }^{82}$ Throughout the SADC region, states score high in terms of their participation and commitment with regard to global agreements, such as UNCLOS and various other international treaties. ${ }^{83}$ The picture changes, however, once the focus narrows to continental agreements where only five out of 16 SADC countries have signed the Lomé Charter. ${ }^{84}$ None of them have ratified the Charter. At a regional level, Angola has signed the Yaoundé Declaration ${ }^{85}$ and only six out of the 16 SADC countries have signed the Jeddah Amendment.

In its evaluation of Africa's maritime enforcement, the Stable Seas Index considers the state of the navies and coastguards of African countries to assess whether they are deemed adequate for monitoring the territorial waters and EEZ of the particular state. ${ }^{86}$ 
In measuring the scope of the need of a particular state in order to control their maritime domain properly, all SADC states showed an inadequate ability, with South Africa scoring less than a number of other SADC states, including its close neighbours Namibia and Mozambique. ${ }^{87}$ SADC states generally scored well in terms of their domain awareness $^{88}$ in their ability to collect, analyse and disseminate information, but once again exhibited relatively poor performance in terms of their coastal patrol assets. ${ }^{89}$ In terms of improving its naval capability in building capacity to enhance its maritime capability, South Africa is regarded as robust, scoring well above the rest of the SADC states. ${ }^{90}$ This would indicate that South Africa should be a leading role player in the SADC maritime security domain.

It is against this backdrop that the importance of participation and support of AIMS 2050, the Jeddah Amendment and the Lomé Charter should be considered. The Stable Seas Index shows that SADC has serious problems within the maritime domain on issues such as illicit trade, ${ }^{91}$ and all forms of trafficking ${ }^{92}$ but that there are no serious concerns regarding piracy; ${ }^{93}$ yet, its Maritime Security Strategy is still focused on dealing with piracy. ${ }^{94}$ There does not seem to be any urgency in addressing matters other than piracy, even if other transnational crimes pose a more severe risk to SADC maritime security. Both the Jeddah Amendment and the Lomé Charter address maritime crimes in addition to piracy and urge co-operation between states to counter these threats; yet, only six SADC countries have signed the Jeddah Amendment and only five have signed the Lomé Charter. This does not bode well for SADC co-operation on matters other than piracy. This is especially true for South Africa, a country that should, on paper at least, arguably have the most to contribute in terms of capacity and adherence to the rule of law.

\section{What should be in place for a regional navy or coastguard?}

Any regional navy or coastguard would have to work within a specific mandate. This would be possible within the framework provided by AIMS 2050 for a naval component to the ASF. Within this framework, one would argue that specific multilateral agreements would not be necessary, unless their application would fall outside the purview of the doctrine and mandate of the ASF, which is set out clearly in the AU Constitutive Act. This would limit the application to peace enforcement scenarios, in which case a navy would probably be the better option.

It is arguable that the maritime security situation, especially within the SADC region, would require a large law enforcement component in order to combat the nature of the maritime security threats. In terms of limitations often placed on military operations, a coastguard would be a viable and legally defensible option in the SADC context.

It is submitted that the SADC is not ready for a regional coastguard or navy. Although the SADC Maritime Security Strategy is in an advanced state of review, the current situation is not conducive to such regional co-operation. Royeppen convincingly argues that different countries within the SADC region would have different maritime practices. This is clear if one considers that the concept of maritime security differs from state to state. The SADC will have to reach a common goal, outside the piracy 
paradigm, that considers all member states, including landlocked states who could, for example, be required to contribute to a regional coastguard, even if it is only in terms of funding, since they will definitely benefit from such a coastguard.

Ultimately, it would depend on political will - the political will to support existing continental and regional declarations and treaties in order to create the international legal framework on which to base the regional navy or coastguard. This further implies the political will to implement strategic components, such as the working group of chiefs of African navies and/or coastguards, which would be critical in facilitating a successful regional force.

\section{CONCLUSION}

When classifying navies, one needs to evaluate the maritime security environment and functions performed by the various maritime organisations in the sometimes hostile maritime domain. Navies normally perform functions relating to military, policing and diplomatic requirements as tasked by the state. This article focused on the policing functions/roles of navies and how this would be better suited to roles traditionally performed by coastguards. Having a coastguard would allow organisations such as the SA Navy to focus on diplomatic functions (and war-fighting preparation) as required by the maritime foreign policy alluded to in this article. The reality, however, reflects a navy required to but hampered in performing policing (coastguard) functions, more often limited to a diplomatic role. This reflects the clear disconnect between the maritime foreign policy ideal and what the SA Navy can deliver as an instrument of foreign policy.

African maritime security forces are currently misaligned in meeting the security threats they face. They have navy bureaucratic affiliations and training programmes but have a predominance of coastguard missions, operate in coastguard zones, and require coastguard partnerships. The regional co-operation on the West Coast of Africa has clearly shown that regional coastguard operations are possible. The security situation in the SADC region reflects the need for a regional coastguard, both in the context of the proliferation of transnational crimes other than piracy and the critical lack of capability of the individual states. States cannot secure their maritime domains on their own. The legal framework for such co-operation already exists. What is absent, however, is the political will in the SADC to find a regional solution.

In the absence of regional co-operation, South Africa should play a leading role in ensuring maritime security, for South Africa as well as the SADC as a region. The nature and roles of navies as well as coastguards are such that, within the South African context, it should not be an either/or situation. South Africa needs both a navy and a coastguard to allow for its strategic and practical situation - or at the very least should consider a hybrid force where the navy and coastguard functions are combined. 


\section{ENDNOTES}

${ }^{1}$ A van Nieuwkerk \& C Manganyi. "South Africa's maritime foreign policy: A conceptual framework". Scientia Militaria (current edition), 2020.

${ }^{2}$ Ibid.

${ }^{3}$ C Bueger. "What is maritime security?". Marine Policy 53. 2015, 159-161.

${ }^{4}$ Ibid., 161.

${ }^{5}$ K Booth. Navies and foreign policy. London: Croom Helm, 1977, 16-25.

${ }^{6}$ A Forbes (ed). "Naval diplomacy and maritime power projection". In Proceedings of the Royal Australian Navy Sea Power Conference. Canberra: Sea Power Centre, 2013, 52-65.

${ }^{7}$ B Lombardi. The future maritime operating environment and the role of naval power. Ottawa: Defence Research and Development Canada, 2016, 67-71.

${ }^{8}$ Booth op. cit., 16.

${ }^{9}$ C Manganyi. "South African naval diplomacy since 1994". Published MMil thesis. Stellenbosch University, 2014. <https://www.google. com/url? sa $=$ t\&rct $=$ i\&q $=\&$ esrc $=$ s\&source $=$ web $\& c d=7 \& v e d=2 a-$ hUKEwjeyK2P 4HiAhUjmeAKHcNwBAgQFjAGegQIBBAC\&url=https $\% 3 \mathrm{~A} \% 2 \mathrm{~F} \% 2 \mathrm{Fscholar}$.sun.ac.za\%2Fbitstream $\% 2 \mathrm{~F}$ handle\%2F10019.1\%2F86420\%2Fmanganyi south 2014. pdf $\% 3$ Fsequence $\% 3$ D2\%26isAllowed\%3Dy\&usg=AOvVaw2BGUL3YFyGlfLjTFTXDJpm> Accessed on 4 May 2019.

${ }^{10}$ L Feldt. Maritime security: New perspectives of a familiar subject - the role of navies, coast guards and NGOs in today's maritime domain. ISPSW Strategy Series: Focus on Defence and International Security 425. Berlin: ISPSW, 2016.

${ }^{11}$ AP Jackson. "Keystone doctrine development in three Commonwealth navies". Pa per presented at the King-Hall Naval History Conference, Canberra, 30-31 July 2009.

${ }^{12}$ G Till. Seapower: A guide for the twenty-first century. London: Frank Cass, 2004.

${ }^{13}$ Jackson op. cit.

${ }^{14}$ G Martin. "Southern Africa is Safe - SA Navy Chief". DefenceWeb. 23 February 2012. <https://www.defenceweb.co.za/sea/sea-sea/southern-africa-is-safe-sanavy-chief/> Accessed on 5 March 2019.

${ }^{15}$ S Stead, K Chitiyo, J Potgieter, G Till. "Maritime development in Africa: An independent specialists' framework". Brenthurst Foundation Discussion Paper 2010/3. Johannesburg: The Brenthurst Foundation, 2010, 8.

${ }^{16}$ H Fouché. "Piracy: The African experience". In Potgieter, TD \& Pommerin, R (eds), Maritime security in southern African waters. Stellenbosch: Sun Press, 2009, 84-86. 
${ }^{17}$ J Germishuys. "SO1 maritime planning at the South African joint operations HQ in Pretoria". Personal interview, 7 April 2014.

${ }^{18} \mathrm{~S}$ Laxmidas. "Tanker hijacked off Angola in Jan returned, minus $\$ 8$ million of diesel". Reuters. 25 February 2014. $<$ http://www.reuters.com/article/2014/02/25/us-angola-sonangol-piracy-idUSBREA1O1IW20140225> Accessed on 20 July 2014.

${ }^{19}$ E Rosand \& J Ipe. "Enhancing counterterrorism cooperation in southern Africa". African Security Review 17/2. 2008, 43-46.

${ }^{20}$ SADC (Southern African Development Community). 10 year SADC strategic plan of action on combating trafficking in persons, especially women and children (2009-2019). Gaborone: SADC Secretariat, May 2009, 1-2.

${ }^{21}$ Gender Links for Equality and Justice. "Human trafficking policy brief”. April 2013. $<\underline{\text { http://www.genderlinks.org.za/article/human-trafficking-2013-04-09> }}$ Accessed on 5 April 2014.

${ }^{22}$ E Onyango. "Dar cited on illegal drug peddling in the SADC region". South African Foreign Policy Initiative. 15 July 2013. < http://www.safpi.org/news/article/2013/dar-cited-illicit-drug-peddling-sadc-region $>$ Accessed on 15 April 2014.

${ }^{23}$ African Armed Forces. "Mozambique purchases naval patrol boats". 1 October 2013. <http://www.aafonline.co.za/news/mozambique-purchases-naval-patrol-boats $>$ Accessed on 8 July 2014.

${ }^{24}$ Stead et al. op. cit., 19-20.

${ }^{25} \mathrm{M}$ Purves. "Illegal, unreported and unregulated fishing and maritime security in southern Africa". In Potgieter \& Pommerin op. cit., 113-116.

${ }^{26}$ MRAG. Study and analysis of IUU fishing in the SADC region and an estimate of the economic, social and biological impacts. Vol. 2, Main report. London, May 2008, 6-7.

${ }^{27}$ Ibid.

${ }^{28} \mathrm{C}$ Khwela. "The importance of port security to maritime security". In Potgieter \& Pommerin op. cit., 31, 40.

${ }^{29}$ D Dillon. "Maritime piracy: Defining the problem". SAIS Review XXV/1. Winter 2005. 157-159.

${ }^{30}$ Stead et al. op. cit., 3

${ }^{31}$ FA Kornegay. "A new approach to Africa'a maritime security". Africa Up Close.

13 December 2018. < https://africaupclose.wilsoncenter.org/a-new-approach-to-africas-maritime-security/> Accessed on 13 March 2020.

${ }^{32}$ African Union. 2050 Africa's Integrated Maritime Strategy. Version 1.0. Addis Ababa, 2012.

${ }^{33}$ Ibid., 10. 
${ }^{34}$ SADC. Towards a common future. 2012. $<$ https://www.sadc.int/sadc-secretariat/ directorates/office-executive-secretary/organ-politics-defense-and-security/> Accessed on 6 March 2020.

35 JPB Coelho. African approaches to maritime security: Southern Africa. Maputo: Friedrich-Ebert-Stiftung Mozambique, 2013, 13.

${ }^{36}$ Ibid., 14.

${ }^{37}$ The SA Navy hosted members of the SADC from 23 to 25 July 2019 to review the strategy and to draft an integrated maritime security strategy, which now has to be ratified by SADC organisation.

${ }^{38}$ LN Sisulu. "Address at the SADC Extraordinary Meeting on Regional Anti-Piracy Strategy". Government Communication and Information System. 2013. $<$ https://www.gov.za/address-1-n-sisulu-mp-minister-defence-and-mili-

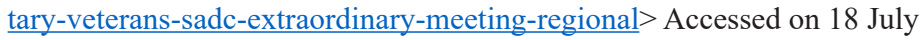
2014.

${ }^{39}$ Personal notes from a South African National Joint Maritime Security Policy and Strategy Workgroup, February 2013.

${ }^{40}$ Safeguarding South Africa includes its people, territory, islands, territorial waters, exclusive economic zone, extended continental shelf, vital interests, resources and critical infrastructure.

${ }^{41}$ The border line does not include ports of entry and border posts. These remain the responsibility of other departments.

${ }^{42}$ Department of Defence. "South African defence review 2015". Chapter 6, 6-1. $<$ http://pmg-assets.s3-website-eu-west-1.amazonaws.com/170512review. pdf> Accessed on 5 March 2019.

${ }^{43}$ B Hlatshwayo. "Operation CORONA: Border safeguarding”. Presentation at the $2^{\text {nd }}$ Annual DefenceWeb Border Control Conference, Pretoria, 7 March 2011. $<$ https://www.defenceweb.co.za/security/border-security/border-security-is-now-a-national-priority-sandf-says/> Accessed on 15 April 2014.

${ }^{44}$ Ibid.

${ }^{45}$ G Martin. "Integrated approach needed for border security - experts". DefenceWeb. 6 September 2013. < https://www.defenceweb.co.za/security/border-security/integrated-approach-needed-for-effective-border-security-experts/?catid=87\%3Aborder-security $>$ Accessed on 15 April 2014.

${ }^{46}$ X Phillip. "Dusting off the Border Management Authority Bill borders on misman agement". Daily Maverick. 25 July 2019. $<$ https://www.dailymaverick. co.za/opinionista/2019-07-25-dusting-off-the-border-management-authority-bill-borders-on-mismanagement/> Accessed on 15 January 2020.

${ }^{47}$ Department of Home Affairs. "Border Management Authority Bill”. 2016. < $\underline{\text { http:// }}$ pmg-assets.s3-website-eu-west-1.amazonaws.com/B9B-2016 border_management authority.pdf $>$ Accessed on 10 January 2020. 
${ }^{48}$ RW Higgs. "Prospects for achieving maritime security in SADC". Presentation at the Institute for Security Studies, Pretoria, 11 April 2014, 9. Personal notes furnished to author.

${ }^{49}$ L Otto. "Mozambique's security cooperation: Protecting the maritime borders". South African Institute of International Affairs. 29 June 2012. < http://www. saiia.org.za/opinion-analysis/mozambiques-security-cooperation-protecting-the-maritime-borders $>$ Accessed on 15 April 2014.

${ }^{50} \mathrm{G}$ Martin. "Operation Copper now only with SA and Mozambique". Neptune Maritime Security. 20 March 2014. $<$ http://www.neptunemaritimesecurity. com/operation-copper-now-sa-mozambique/>Accessed on 15 April 2014.

${ }^{51}$ SAMSA (South African Maritime Safety Authority). "Sea watch and response overview". <http://www.samsa.org.za/service/rescue-co-ordination> Accessed on 15 April 2014.

${ }^{52}$ A. Kampfer. Hydrographer SA Navy. Interview with the Hydrographer on 11 April 2014.

${ }^{53}$ Department of Defence. "The South African Defence Review 2014". 25 March 2014. $<$ http://www.gov.za/documents/detail.php?cid=402524 $>$ Accessed on 1 June 2014, Chapter 9, 8-1, 8-2.

${ }^{54}$ Kampfer op. cit.

${ }^{55}$ Standing Maritime Committee of the ISDSC. "Minutes of the 18th meeting of the Work Group to the Standing Maritime Committee (SMC) of the Interstate Defence and Security Committee (ISDSC)", Durban, 21-22 February 2012. $<$ http://www.navy.mil.za/SMC/2012/Minutes\%20of\%2018th\%20Meeting\%20(English).pdf $>$ Accessed on 15 April 2014.

${ }^{56}$ BH Teuteberg. "Africa's Strategy for Maritime Security: A SA Navy perspective". Presentation notes, Pretoria, 2010.

${ }^{57}$ A van Nieuwkerk \& C Manganyi. "South Africa's maritime foreign policy: A conceptual framework". Scientia Militaria (current edition), 2020.

${ }^{58}$ A Vogel. "Navies versus coast guards: Defining the roles of African Maritime Security Forces". Africa Security Brief 2. 2009.

${ }^{59}$ P. Paleri. "Coast guards of the world and emerging maritime threats". Ocean Policy Research Foundation. Special edition. 2009. < http://fields.canpan.info/report/download?id=3288 $>$ Accessed on 3 May 2019. P 48-51.

${ }^{60} \mathrm{G}$ Martin. "Department of Defence looking at establishing a coast guard". Defence Web. 20 September 2017. $<$ https://www.defenceweb.co.za/sa-defence/ sa-defence-sa-defence/department-of-defence-looking-at-establishing-coast-guard/> Accessed on 3 May 2019.

${ }^{61}$ Global Ocean Commission. From decline to recovery: A rescue package for the global ocean. Global Ocean Commission report. Oxford, 2014, 8. 
${ }^{62}$ Neither the founding Charter of the Organization of African Unity of 1963 nor the 2002 African Union Constitutive Act contain any explicit reference to the sea, inland waterways or lakes. See in the regard J Stockbruegger. "Reclaiming the maritime? The AU's New Maritime Strategy". Piracy Studies. 2014. <http://piracy-studies.org/reclaiming-the-maritime-the-aus-new-maritime-strategy/>Accessed on 15 April 2014.

${ }^{63}$ R Gilpin. "Examining maritime insecurity in Eastern Africa". Soundings 8. January 2016. 1.

${ }^{64} \mathrm{D}$ Games. "Finding fortune at the bottom of the ocean: Africa's blue economy prospects are exciting but not without challenges". African Development Week Roundup. Day 4. 2016. 7.

${ }^{65}$ See as example the keynote address of the International Conference on Maritime and Energy Security, where Gen. D. Rodriguez cited regional cooperation as conducive to operational success in the maritime domain. $<$ https://www. africom.mil/media-room/Article/26653/africom-commander-speaks-at-maritime-conference-in-angola $>$ Accessed on 11 August 2019. This stance was subsequently reflected in the resultant Luanda Declaration of 2015.

${ }^{66}$ B Wilson \& L Jacobson. "African maritime security and law enforcement primer". US Department of State. 2019. <https://papers.ssrn.com/sol3/papers.cfm?abstract id $=3394480>$ Accessed on 10 August 2019, 2 .

${ }^{67}$ United Nations, Division for Ocean Affairs and the Law of the Sea. "Chronological lists of ratifications of, accessions and successions to the Convention and the related Agreements". 3 April 2018. < http://www.un.org/depts/los/reference_files/chronological_lists_of_ratifications.htm $>$ Accessed on 10 August 2019.

${ }^{68}$ United Nations. "United Nations Convention on the Law of the Sea". 1982. < $\underline{\text { https:// }}$ www.un.org/depts/los/convention_agreements/texts/unclos/unclos_e.pdf $>$ Accessed on 10 August 2019.

${ }^{69}$ African Maritime Domain.

${ }^{70}$ Article 19 of AIMS 2050. African Union. 20500 Africa's Integrated Maritime Strategy $<$ https://au.int/en/documents-38 $>$ Accessed on 11 August 2019.

${ }^{71}$ http://www.imo.org/en/OurWork/Security/PIU/Documents/DCoC\%20English.pdf.

${ }^{72}$ See PF Brits \& M Nel. "Maritime security and the Lomé Charter: Reality or dream?" African Security Review 27/3-4. 2018. 229. The Djibouti Code can be regarded as widely accepted within the region, considering that it has been signed by 20 out of an eligible 21 countries. 
${ }^{73}$ The Djibouti Code of Conduct was amended in 2017 by the Jeddah Amendment to the Djibouti Code of Conduct in order to expand the scope to include other transnational crimes that threaten maritime security, rather than limiting it to piracy. The amendment was signed by 12 members out of an eligible 17, once again indicating its wide acceptance. Another three states have also subsequently signed. See in this regard International Maritime Organization. "Djibouti Code of Conduct". 2020. <http://www.imo.org/en/OurWork/Security/PIU/Pages/DCoC.aspx $>$ Accessed on 10 August 2019.

${ }^{74}$ ECOWAS. <http://www.imo.org/en/OurWork/Security/WestAfrica/Documents/ code_of_conduct $\% 20$ signed $\% 20$ from $\% 20$ ECOWAS $\% 20$ site.pdf $>$ Accessed on 25 March 2020.

${ }^{75} \mathrm{~K}$ Jacobsen \& J Nordby. Maritime security in the Gulf of Guinea. Copenhagen: Royal Danish Defence College Publishing House, 2015, 28-29.

${ }^{76}$ Zone 1: Mauritania, Senegal, Gambia, Guinea Bissau and Cape Verde. Zone 2: Guinea, Sierra Leone, Liberia, Ivory Coast and Ghana. Zone 3: Togo, Benin, Nigeria, Cameroon and Equatorial Guinea. Zone 4: Gabon, Sao Tome and Principe, Congo, Democratic Republic of the Congo and Angola. Bold countries indicate location of coastguard centres.

${ }^{77}$ African Maritime Safety and Security Agency. "Integrated Coastguard Network West-Central Africa". $2010<$ http://www.amssa.net/ICGNwest-centralAfrica.aspx $>$ Accessed on 3 October 2015.

${ }^{78}$ African Union. <https://au.int/en/treaties/african-charter-maritime-security-andsafety-and-development-africa-lome-charter $>$ Accessed on 13 August 2019.

${ }^{79}$ Brits \& Nel op. cit., p. 234.

${ }^{80}$ To date the Lomé Charter has only be signed by 35 African countries and has been ratified by one.

${ }^{81}$ In general, see the Stable Seas Index available at $<$ https://stableseas.org/issue-areas/ overview\#0>Accessed on 13 August 2019.

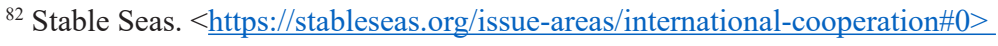
Accessed on 13 August 2019.

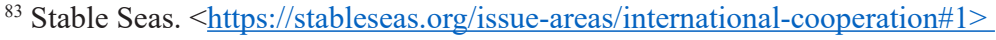
Accessed on 13 August 2019.

${ }^{84}$ Stable Seas. $<$ https://stableseas.org/issue-areas/international-cooperation\#2> Accessed on 13 August 2019.

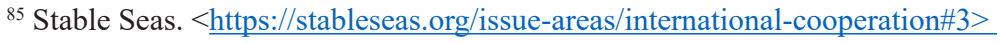
Accessed on 13 August 2019.

${ }^{86}$ Stable Seas. $<\underline{\text { https: } / / \text { stableseas.org/issue-areas/maritime-enforcement } \# 0>}$ Accessed on 13 August 2019.

${ }^{87}$ Stable Seas. $<\underline{\text { https://stableseas.org/issue-areas/maritime-enforcement\#1 }>}$ Accessed on 13 August 2019. 
${ }^{88}$ Stable Seas. $<$ https://stableseas.org/issue-areas/maritime-enforcement $\# 2>$ Accessed on 13 August 2019.

${ }^{89}$ Stable Seas. $<$ https://stableseas.org/issue-areas/maritime-enforcement $\# 3>$ Accessed on 13 August 2019.

${ }^{90}$ Stable Seas. $<$ https://stableseas.org/issue-areas/maritime-enforcement $\# 4>$ Accessed on 13 August 2019.

${ }^{91}$ Stable Seas. $<\underline{\text { https://stableseas.org/issue-areas/maritime-enforcement } \# 4>}$ Accessed on 13 August 2019.

${ }^{92}$ Stable Seas. $<$ https://stableseas.org/issue-areas/maritime-mixed-migration $\# 0>$ Accessed on 13 August 2019.

${ }^{93}$ Stable Seas. $<$ https://stableseas.org/issue-areas/piracy\#0>Accessed on 13 August 2019.

${ }^{94}$ A. Royeppen. "Rethinking challenges to SADC's Maritime Security Model". Institute for Global Dialogue. 2018. $<$ https://www.igd.org.za/infocus/11204-rethinking-challenges-to-sadc-s-maritime-security-model> Accessed on 10 August 2019. 